\title{
USE OF LABELLED IRON FOR DETERMINING THE INTENSITY OF ERYTHROPOIESIS ON THE BASIS OF FERROKINETIC MEASUREMENTS
}

\author{
J. VÁCHA, V. ZNOJIL
}

Institute of Biophysics of the Czechoslovak Academy of Sciences, 61265 Brno

Received October 17, 1986

\begin{abstract}
$\mathrm{V}$ á c h a J., V. Z $\mathrm{n} \circ \mathrm{j} i \mathrm{i}$ : Use of Labelled Iron for Determining the Intensity of Erythropoiesis on the Basis of Ferrokinetic Measurements. Acta vet. Brno,56, 1987: $31-40$.

The determination of the intensity of erythropoiesis in mammals remains something of a problem, presupposing knowledge of the iron metabolism in the erythropoietic organs and elsewhere. On the basis of our ferrokinetic studies in mice, we present a synopsis of methods of how to use labelled iron for determining the intensity of erythropoiesis in various experimental situations. In the majority of cases, it is possible to do so routinely with sufficient accuracy and an acceptable degree of laboriousness. But for very precise measurements, or under special circumstances when e.g., the metabolism of iron changes drastically under the influence of some drugs, a complex ferrokinetic analysis must be made, requiring rather sophisticated formal (mathematical) analysis.
\end{abstract}

Ferrokinetics, erythropoiesis, haematological methods, mice.

The exact but simple determination of the intensity of erythropoiesis remains something of a problem. Neither microscopic nor cultivation methods with erythroid cells in vitro provide a quantitatively exact answer, so that there is no alternative to developing the ferrokinetic methods, which have temporarily fallen into disuse.

We have concerned ourselves with the relation between ferrokinetics and erythropoiesis in mice in some depth. Though there is no space here to deal with the details of our work, particularly the mathematical modelling of ferrokinetics, we shall try to give here practical guidance on the measurement of erythropoiesis in physiological and pathophysiological practice. The theoretical background can be found in the literature cited.

Table 1 shows various methods of determining the intensity of erythropoiesis using labelled iron (most of ten ${ }^{59} \mathrm{Fe}$ ) in order of reliability, but also, of course, in order of laboriousness. The first three can be carried our routinely, but in some pathological conditions of erythropoiesis are subject to error. The last two are universal and can in principle take into account any irregularities, but require a certain amount of experience 


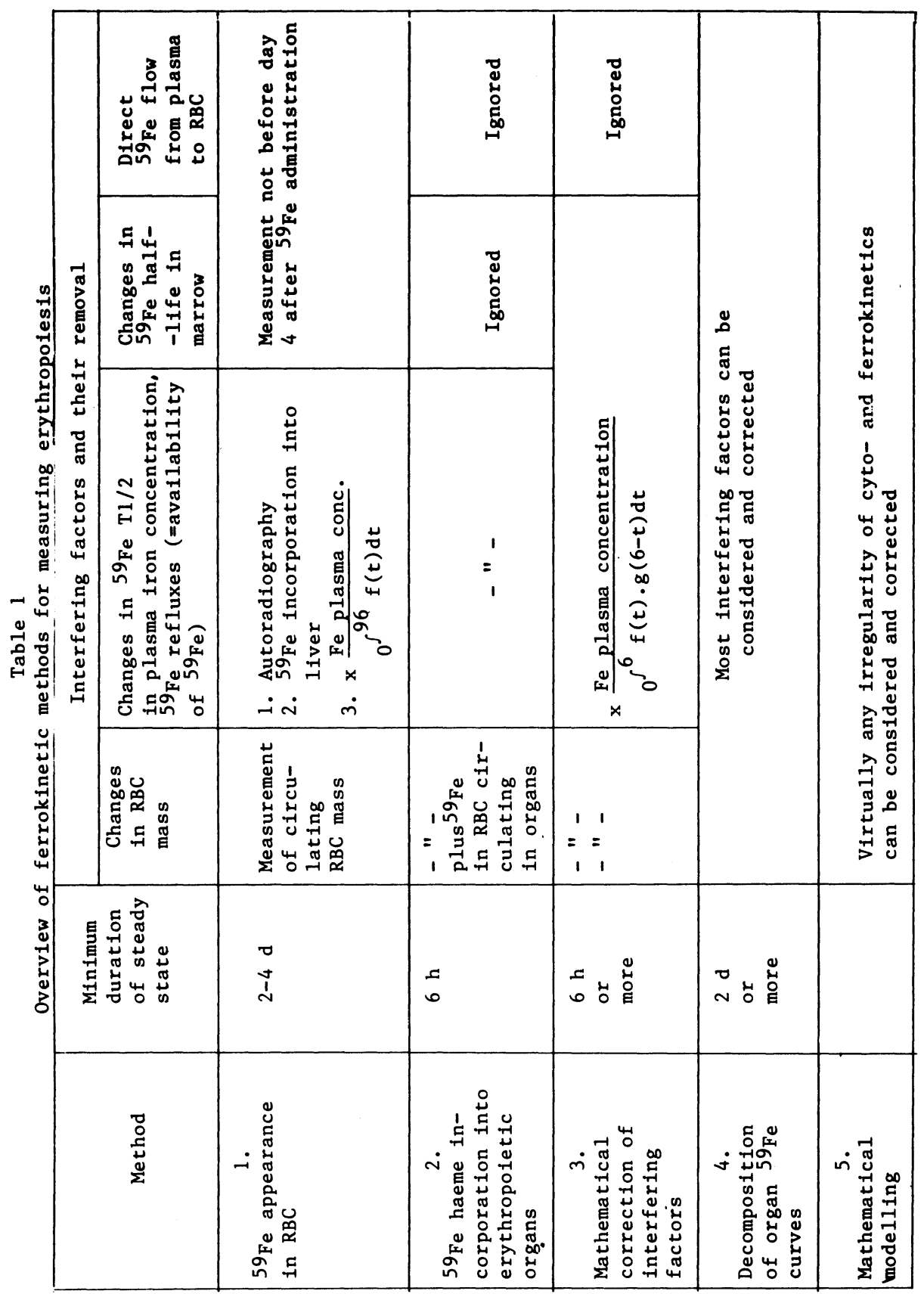


with biomathematical procedures. All methods presuppose a complete binding of labelled iron to the plasma transferrin when more exact work is needed; we have developed an appropriate microtechnique for use on small laboratory animals ( $\mathrm{H} \circ \mathrm{l}$ á et a1. 1979).

The first method of measuring the intensity of erythropoiesis is based on ${ }^{59} \mathrm{Fe}$ appearance in the red blood cells (RBC). Figure 1 shows the increase in radioactivity in circulating erythrocytes of mice following the intravenous administration of $59 \mathrm{Fe}$. The measuring of the radioactivity of rinsed erythrocytes at a given interval after ${ }^{59} \mathrm{Fe}$ administration is technically the simplest method and routine one; however, without some further measurements it is rather unreliable.

The choice of interval is important, since in each section of the erythrocyte ${ }^{59} \mathrm{Fe}$ appearance curve there are different disturbing factors at work. If in a given experimental situation (such as a postirradiational state) there is a change in the volume of the circulating erythrocyte mass, this volume must be measured, and measured using labelled erythrocytes, not only plasma and venous haematocrit. It is then possible to convert the curve for the total circulating erythrocyte mass, as was done in the figure (experimental data from $V$ á $c h$ a et $a 1.1982$ b were used here).

The whole erythrocyte ${ }^{59} \mathrm{Fe}$ appearance curve is further affected by the availability of labelled iron in the plasma, which itself depends, inter alla on the intensity of erythropolesis itself. With low availability a smaller number of labelled atoms is incorporated into each erythroid cell and an appropriate correction must be made. This can be done either autoradiographically, by counting the number of grains per cell, or using $59 \mathrm{Fe}$ incorporated into the liver, or by calculation. The ${ }^{59} \mathrm{Fe}$ incorporation in the meticuously perfused liver (in situ) can be regarded as an indicator of tracer accessibility where there are small deviations of the ferrokinetics from a steady state. When the ${ }^{59} \mathrm{Fe}$ incorporation into the liver falls to $80 \%$ of control values in experimental animals in the incorporation interval chosen, it is necessary to multiply the magnitude of tracer incorporation into the erythrocytes $1 / 0.8=1.25$ times.

Carrying out a correction by means of calculation presupposes knowledge of the $59 \mathrm{Fe}$ clearance curve and of plasma iron concentration; it follows the formula given in Tab. 1. The correction (multiplying) factor is given as a ratio of plasma iron concentration and an integral of the $f(t)$ function, i.e. of the clearance curve during the whole duration of incorporation. (Even trace quantities of haemolyzed erythrocytes in plasma samples interfere greatly in the late phases of the clearance curve. Therefore the haemoglobin must be precipitated from plasma by means of trichloroacetic acid, and possibly also a correction should be made for the unprecipitable fraction in erythrocytes - $\mathrm{H}$ o 1 á et al. 1975, $\mathrm{V}$ á $\mathrm{c} \mathrm{h}$ a et al. $1982 \mathrm{~b}$ ). In concrete situations it could be possible to omit some components of the calculation correction for the iron availability; this question could not be solved generally, however.

The initial part of the erythrocyte ${ }^{59} \mathrm{Fe}$ appearance curve is also affected by the fact that the amount of iron by-passing directly into circulating erythrocytes can alter. Under physiological conditions this iron represents $13-14 \%$ of the total Fe content in mature erythrocytes ( $\mathrm{P}$ a$\mathrm{p} a \mathrm{y} a \mathrm{n} \circ \mathrm{p} \circ \mathrm{u} 1 \circ \mathrm{u}$ and $\mathrm{F} i \mathrm{n} \mathrm{h}$ 1975). Changes in this component are detectable only by complex ferrokinetic analysis. In the case of the method No 1 this complication is avoided if the sample is examined at a sufficiently long interval after 59 Fe administration, preferably not before 4 days ( 96 hours). - In the central part of the curve cytokinetic changes may also make themselves felt, such as a shortening of the stay 


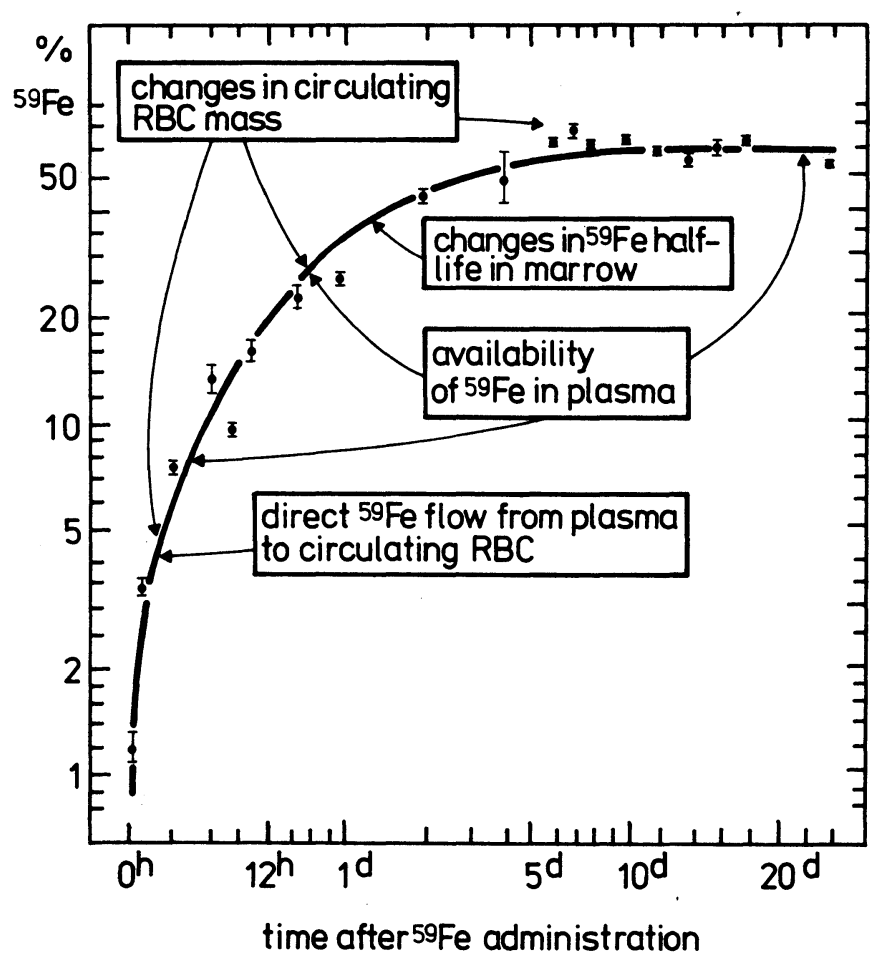

Fig. 1. Interfering factors in the method of appearance of labelled iron in circulating erythrocytes ( $R B C$ ) of mice as a function of time elapsed since the $59 \mathrm{Fe}$ administration.

of mature retictlocytes in the marrow, which shortens the $59 \mathrm{Fe}$ half life there. The way round this is the same as in the previous case, 1.e. to wait long enough after ${ }^{59} \mathrm{Fe}$ administration.

However, a prerequisite of the method of the ${ }^{59} \mathrm{Fe}$ appearance in erythrocytes is for the intensity of erythropoiesis not to alter between the tracer administration and measurement (1.e., e.g., for 4 days). The method does not, of course, give any information about the share of individual localities in erythropolesis.

Method No 2 is the measurement of the radioactivity of haemopoletic organs at a suitable interval after ${ }^{59} \mathrm{Fe}$ administration, usually a much shorter one than in the case of method No 1. Thus it is not anticipated that the state will remain constant for so long, which is especially important, e.g., following acute irradiation. But this method also suppose that many corrections will be made. Above all it is necessary to use the whole of the 
INTERFERING FACTORS IN HAEME 59Fe TURNOVER IN BONE MARROW

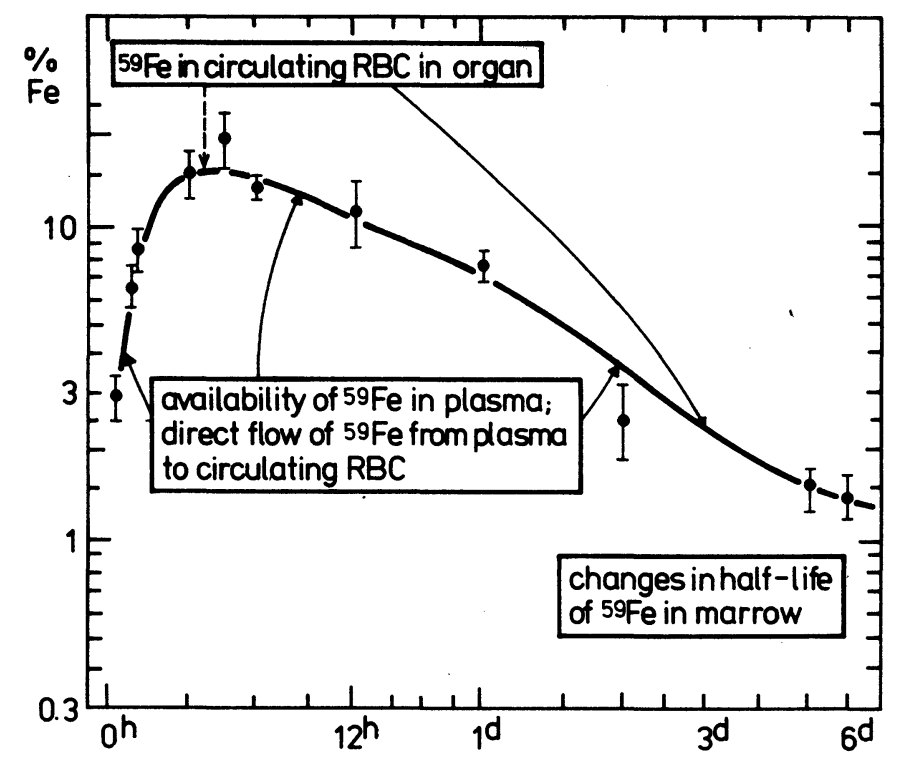

time after ${ }^{59} \mathrm{Fe}$ administration

Fig. 2. Interfering factors in the method of appearance of labelled iron in the haeme fraction of an erythropoletic organ (here of the whole bone marrow in mice) as a function of time elapsed since the $59 \mathrm{Fe}$ administration.

bone marrow, since the erythroid marrow is distributed unevenly in the skeleton ( $\mathrm{V}$ á $\mathrm{c} \mathrm{h}$ a et al. 1982 a) and since different types of bone have different ferrokinetics ( $V$ a $c h$ a et al. 1984 b). For the mechanical removal of soft tissue from bone we employ Dermestes vulpinus Fbr. beetles, which are simple to rear ( $\mathrm{r}$ u 1 i c h 1977). - It is of basic importance to know how to distinguish the haeme and non-haeme iron in the marrow, since, for instance, after acute irradiation the proportion of $59 \mathrm{Fe}$ incorporation into the non-haeme fraction increases sharply, and the fall in erythropolesis as such could be completely masked. We have therefore developed a method of haeme iron extraction from tissue using acid ethylacetate ( $V$ á $c h$ a et a1. 1978).

Fig. 2 shows the curve of the radioactivity in the haeme fraction of the skeleton plotted against time following 1.v. tracer administration (according data from Vá c h a et-a1. 1982 b). It is a good idea to withdraw material around the maximum of the curva, i.e. about $6 \mathrm{~h}$ after 1.p. $59 \mathrm{Fe}$ administration. If the fall in erythropolesis is very pronounced, as, for instance in the initial days following a dose of several $\mathrm{Gy}$, a major disturbing factor is the presence of radioactivity in erythrocytes circulating in the bone marrow or spleen (it appears even under physiological 


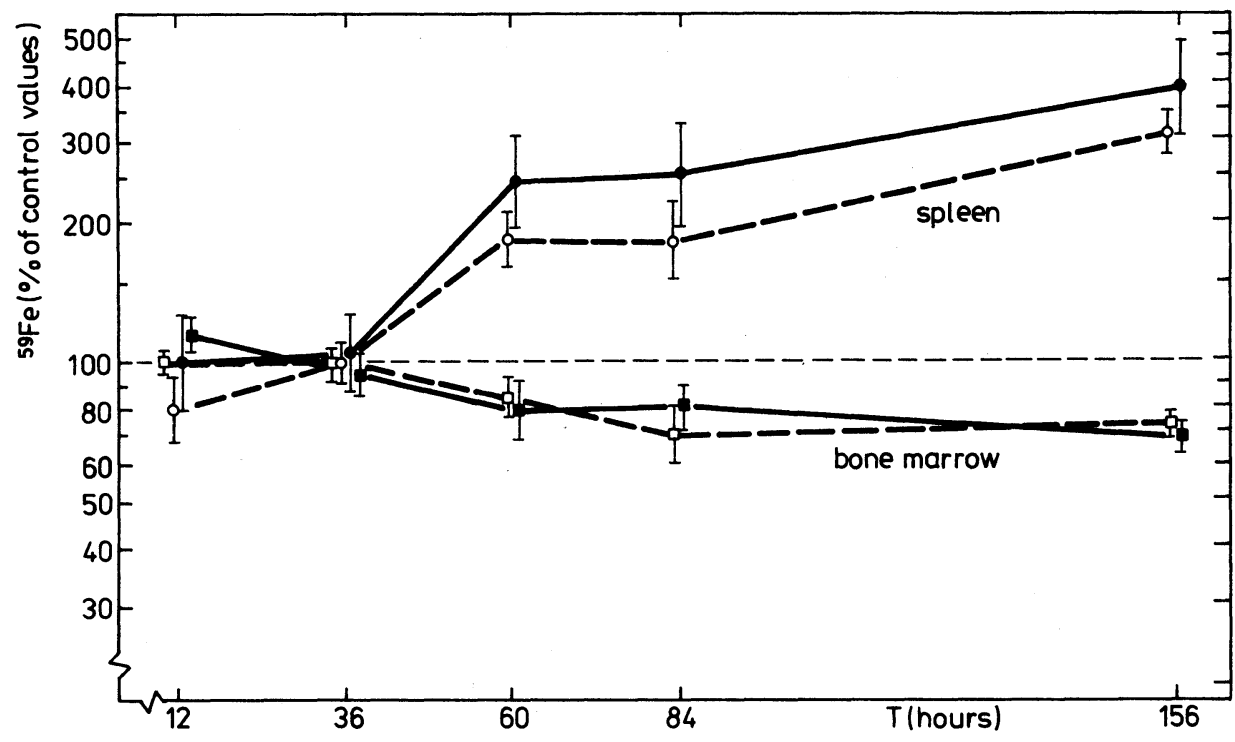

Fig. 3. An example of a paradox of ${ }^{59} \mathrm{Fe}$ incorporation: ${ }^{59} \mathrm{Fe}$ values after $6 \mathrm{~h}$ incorporation into the bone marrow and spleen plotted against time elapsed after the start of thyroid hormone administration (as a percentage of controls). Bars - S.E., circles - spleen, rectangles - bone marrow, full symbols - haeme ${ }^{59} \mathrm{Fe}$, open symbols total ${ }^{59} \mathrm{Fe}$.

conditions in the late phases of the curve), and allowance must be made for this. For this purpose we have published the volumes of erythrocytes in individual parts of the skeleton of mice under physiological conditions and following sublethal irradiation ( $V$ á $c h$ a et.al. 1980); it is then sufficient to know the radioactivity of the aliquot of the erythrocyte mass in order to make a correction.

As in the case of method No 1, here, too, the availability of iron in the plasma, changes in the rate at which mature erythrocytes are released from the organ into the periphery, and changes in the direct flux of ${ }^{59} \mathrm{Fe}$ from plasma to erythrocytes all play a role. The changed availability of iron could be regarded in the same way as with method No 1 , only the integration time (tracer incorporation) will be shorter. The remaining two factors could not be corrected using mere organ measurements. If the three factors mentioned are not taken into consideration, this simple method may fail. So, for instance, it happened to us, in a situation where erythropoiesis had been stimulated for some time by the administration of thyroid hormones (time of administration on $x$ axis, Fig. 3) that the ${ }^{59} \mathrm{Fe}$ incorporation into the bone marrow fell below $80 \%$, though a detalled ferrokinetic analysis showed erythropoiesis in the marrow in fact to be increased to $114 \%$ (unpublished observation).

How, then, is one to improve the method to take into account some at least of these disturbing factors? For the ordinary user of ferrokinetics 
we have proposed a stereotyped procedure, an equation where appropriate values could be substituted with some assistence from a biomathematician (method No. 3 in Tab. 1). Unlike the previous procedures, it assumes the additional determination of the plasma iron clearance curve and measurement of the plasma iron concentration. According to this method the $59 \mathrm{Fe}$ clearance curve is determined in the first $6 \mathrm{~h}$, and the least squares method is used to obtain from it the constants $b, a_{1}$, and $a_{2}$ of the equation

$$
f(t)=b \cdot e^{-a_{1} t}+(1-b) e^{-a_{2} t} \text {. }
$$

The mean concentration of plasma iron (C) in the plasma samples is determined at the same time. (The influence of the possible spontaneous fluctuation of plasma iron concentration is effectively excluded by parallel use of control animals.) In animals assayed $6 \mathrm{~h}$ after $59_{\mathrm{Fe}}$ administration haeme iron is also extracted from erythropoletic organs and the radioactivity (A) of the extract measured; at the same time the radioactivity of $100 / \mathrm{ul}$ erythrocytes in the peripheral blood is measured. The intensity of erytiropolesis in an organ is given by the expression

$$
H=\frac{A-E}{D} \cdot C \text {, }
$$

where $D=0_{0}^{f^{6}} f(t) \cdot g(x) d t$.

The function $g(x)$ expresses the disappearance of labelled haeme iron from the organ (as a result of the release of mature erythrocytes), and it can be expressed in the form

$$
g(x)=e^{-a} 3^{x},
$$

where $x$ is the difference $(6-t)$ in hours. The exponent $a_{3}$ can, according to our model calculations, be taken as 1.8 for the mouse spleen, 1.7 for skeletal localities; in our experience it remains substantially unchanged e.g., by acute irradiation. But if one must expect changes in the kinetics of erythrocyte release from the haemopoietic organs, i.e. In the half life of $59 \mathrm{Fe}$ in the marrow, there it is necessary to supplement the investigation of organ haeme extract radioactivity by a number of measurements on ine descending part of the curve (it comes into play mainly under conditions of enhanced erythropoiesis). Calculation of the integral (3) could in a number of cases be effectively replaced by mere planimetring the area below the organ ${ }^{59} \mathrm{Fe}$ haeme curve.

The method described does not usually require a steady state longer than $6 \mathrm{~h}$ and it is proof against the disturbing effect of changes in the availability of labelled iron and the effect of changes in the kinetics of erythrocyte release from the erythropoletic organs, i.e. a change in the constant $a_{3}$. It does not, however, take into account cases where $59 \mathrm{Fe} \mathrm{by-}$ passes the marrow and spleen and for the most part is incorporated directly from plasma into circulating reticulocytes.

Generally it should be said when comparing methods 1 - 3 that methods 2 and 3 indicate the haeme production in the haemopoletic organs but not the final saturation of circulating erythrocytes with haeme, and they could therefore be wrong even regarding the quantum of cells actually produced. Organ radioactivity measurement is more appropriate where the study of quick and drastic changes of erythrcpoies is are in focus, though its precision is lower. The measurement of erythrocyte radioactivity is able to detect even smaller differences in the total erythrocyte production than organ measurements; it cannot, however, detect the share of individual organs in these changes, and it presupposes a much longer duration of the steady state 
of erythropoles1s. - Under conditions of decreased erythropotesis it is better to use the measurement of ${ }^{59} \mathrm{Fe}$ incorporation Into organs than into the erythrocytes. These cells can continue in the tracer incorporation from plasma still for some time after the fall of erythropoiesis, and so mask the real extent of this fall. In organs measurement it is more appropriate to use $59 \mathrm{Fe}$ bound to haeme than the total $59_{\mathrm{Fe}}$ under conditions of depressed erythropolesis, since storage and other non-haeme fractions of organ Fe usually grow when the erythrocyte production falls. - Under conditions of enhanced erythropoiesis the tracer incorporation into peripheral erythrocytes is a more adequate indicator of red cell production, at the organ measurements do not take into account the possibility that the direct incorporation of $59 \mathrm{Fe}$. into circulating erythrocytes from plasma rises, so that the real rise is underestimated and a paradoxical $59 \mathrm{Fe}$ incorporation fall could possibly take place. Provided we use organ measurements under the conditions of enhanced erythropoiesis, it is better to make use of the total ${ }^{59} \mathrm{Fe}$ incorporation (not only that into the haeme fraction as indicated in formulae $2-4$ ), as the composition of erythroid populations in the marrow is usually shifted to younger forms with a decreased degree of iron haemization and the storage iron plays a relatively small role. A similar situation could obviously take place also at an iron lack in an organism.

So it is obvious that the simple technique 1 to 3 have their limitations, depending on the method. This compels us to seek a more universal and suitable techniques. Using method No 4 it is presupposed that we measure the time course of radioactivity after ${ }^{59} \mathrm{Fe}$ administration not only in plasma, but in circulating erythrocytes and in erythropoietic organs, too. The curves obtained are decomposed by calculation into exponential components, their changes against the controls in the experimental situation given are characterized, and on that basis a rough calculation of changes of ferrokinetics is made. Also the conventional haematological measurements in peripheral blood are of use here, of course; all parameters need to be synthesized on the basis of model ideas so as to give a consistent whole. (Under model ideas one need not understand here the actual mathematical model, but only a construction of thought giving a consistent picture of the structure of the erythropoletic system and of changes taking place in it.) It is evident, of course, that in method No. 4 it is not possible to speak about a consistency of the resulting picture with a mathematical strictness. It is also advisable to test in all cases an overall balance of the iron distribution between the organ and tissue assayed on the one hand and the rest of the body on the other; we could observe, e.g., the establishment of a new steady state of ferrokinetics in mice treated with glucan, in which a new, large iron compartment arose, localized beyond the organs assayer and the blood, and competing with plasma. It is only possible to obtain an accurate picture of the interplay of iron fluxes between individual compartments and of changes in them following changes in the intensity of erythropoiesis using mathematical modelling involving the methods of compartment analysis (V á c h a et al. 1984a, V á c h a et al. 1982b, V á c ha et al. 1984b). It is possible by means of modelling to breakdown of the summary curve of $59 \mathrm{Fe}$ incorporation into an erythropoietic organ by components, and thus" separate what we are interested in, i.e. mainly the component corresponding to the iron bound immediately with erythropolesis.

To summarize, then, it can at present be said that it is possible routinely to measure the intęnsity of erythroposis in most situations occuring in the pathophysiology of mammals, and to do so with sufficient accuracy and an acceptable degree of laboriousness. But for very precise measurement, or under certain special circumstances, a complex ferrokinetic analysis must be made, requiring ra her sophisticated formal analysis. 
Použití značeného železa pro určováni intensity erythropoesy pomoci ferrokinetickych měrení

Měření intensity erythropoesy u savců zůstává stále do jisté míry problémem, vyžadujícím znalost metabolismu železa $v$ krvetvorných orgánech i jinde. Na základé svých ferrokinetických studí u myši přinášíme přehled metod, jak využívat značeného železa ke stanovení intensity erytropoesy v různých pokusných situacích. Ve většině situací je možno dojít $\mathbf{k}$ cíli rutinním postupem $s$ dostatečnou přesností a přijatelným stupněm obtížnosti. Pro velmi přesná měření a za zvláštních okolností, kdy se např. pod vlivem některých farmakologicky účinných látek výrázně mění metabolismus železa, je však třeba provést komplexní ferrokinetický rozbor, předpokládající použití rafinovanějších formálních (matematických) prostředků.

Применение меченного железа для установления интенсивности эритропоэза при помощи феррокинетических измерений

Измерение интенсивности эритропоэза у млекопитающих постояанно остаетця в определенной степени проблемой, требуюшей знаний о метаболизме железа в кроветворных органах и других местах. На основании собственного изучения феррокинетики $y$ мышей предлагаем обзор методов по применению меченного железа для определения интенсивности эритропоэза в различных экспериментальных ситуациях. В больщинстве случаев возможно достижение цели при помощи рутинных приемов с достаточно больщой точностью и приемлимой степенью трудности. Дла очень точных измерений и в особых случаях, когда например под влиянием некоторых фармакологически действенных веществ выразительно изменяется метаболизм железа, необходимо произвести комплексный феррокинетический разбор, предполагающй применение более рафинированных формальных (математических) средств.

\section{References}

GRULICH, I.: Osteologische Präparation mit der Verwendung der kadaverikolen Käfer (Dermestes vulpinus Fbr., Coleoptera, Insecta). Lynx (Prague) n.s., 19/1977: 87-98.

HOLA, J., VACHA, J., BOHACEK, J.: The preparation of ${ }^{59} \mathrm{Fe}$-labelled transferrin of high radioactivity for ferrokinetic studies on small laboratory animals. Acta Haemat., 61 : 55-56, 1979.

HOLA, J. VACHA, J., ZNOJIL, V., KLEINWACHTER, V.: Studies on non-haemoglobin erythrocyte iron; the influence of haemolysis on plasma iron determinations. Clinica Chimica Acta, 61 : 121-126, 1975.

PAPAYANNOPOULOU, T., FINCH, C.A.: Radiation measurement of red cell maturation. Blood Cells, $1: 535-546,1975$.

VACHA, J., DUNGEL, J., HOLA, J., ZNOJIL, V.: The distribution of the haeme and non-haeme fractions of iron in individual regions of the erythropoietic system of intact and acutely irradiated mice Exp. Hematol., 11 : 714-720, 1984a.

VACHA, J., DUNGEL, J., KLEINWÄCHTER, V.: Determination of heme and non-heme iron content of mouse erythropoietic organs. Exp. Hematol, $6: 718-$ $724,1978$. 
VACHA, J., HOLA, J., DUNGEL, J., ZNOJIL, V.: The volume of plasma and erythrocytes in individual bones and in the spleen of mice under physiological conditions and with acute radiation-induced atrophy of the haemopoletic tissue. Acta Haemat., 64: 165-171, 1980.

VACHA, J., HOLA, J., DUNGEL, J., ZNOJIL, V.: The distribution of erythropolesis over the various anatomical regions of the erythropoiotic system in some inbred strains of mice. Exp. Hematol., $10: 768-773,1982 a$.

VACHA, J., ZNOJIL, V., TOLA, J., DUNGEL, J.: The internal iron kinetics in mice. Acta vet. Brno, 51 : 3-22, $1982 \mathrm{~b}$.

VACHA, J., ZNOJIL, V., HOLA, J., DUNGEL, J.: Iron kinetics in individual bone marrow regions (bones) in mice. Acta vet. Brno, 53 : 119-136, $1984 \mathrm{~b}$. 